\title{
Crise da Jurisdição e a Resolução n. 179/2017 do Conselho Nacional do Ministério Público: é possível o ajustamento de conduta em matéria de improbidade administrativa?
}

\author{
Crisis of the Jurisdiction and Resolution n. 179/2017 of the National Council \\ of the Public Prosecutor: is it possible to adjust conduct in matters of \\ administrative impropriety?
}

\author{
Mateus Bertoncini ${ }^{1}$ \\ ${ }^{1}$ Centro Universitário Curitiba (UNICURITIBA), Curitiba - PR, Brasil.
}

\begin{abstract}
Resumo: Este estudo analisa a Resolução n. 179/2017-CNMP, que regulamentou, no âmbito do Ministério Público, a tomada de compromisso de ajustamento de conduta. Discute-se a natureza, o objeto, a competência e o impacto desse mecanismo de solução extrajudicial de conflitos diante do problema da crise da jurisdição existente no Brasil. Também se avalia a Resolução no que se refere à expressa possibilidade de sua utilização em matéria de improbidade administrativa, em aparente contrariedade à Lei n. 8.429/1992. A partir de pesquisa bibliográfica e do emprego do método dedutivo, conclui-se o artigo apontando-se as possibilidades e os limites do ato do CNMP.
\end{abstract}

Palavras-chave: Resolução n. 179/2017 do Conselho Nacional do Ministério Público. Crise da Jurisdição. Compromisso de Ajustamento de Conduta. Improbidade Administrativa. Possibilidades e Limites.

\begin{abstract}
The study examines the Resolution $\mathrm{n}$. 179/2017-CNMP, which regulates, within the scope of the Public Prosecutor's Office, the commitment to conduct adjustment. The nature, object, competence, and impact of this out-of-court dispute resolution mechanism is studied in the face of the crisis of jurisdiction in Brazil. The Resolution also evaluates with regard to the manifest possibility of its use in matters of administrative impropriety, in apparent contradiction to Law n. 8.429/1992. From a bibliographical research and the use of the deductive method, the study concludes pointing out the possibilities and the limits of the act of the CNMP.
\end{abstract}

Keywords: Resolution n. 179/2017 of the National Council of the Public Prosecutor's Office. Crisis of Jurisdiction in Brazil. Commitment to Adjust the Conduct. Administrative Misconduct. Possibilities and Limits of Resolution n. 179/2017-CNMP.

Recebido em: 1\%04/2018

Revisado em: 16/07/2018

Aprovado em: 09/08/2018 


\section{Introdução}

A Lei n. 8.429, de 2 de junho de 1992, conhecida como Lei de Improbidade Administrativa (LIA), representou nos seus primeiros 25 anos de vigência verdadeira mudança de paradigma no combate à corrupção na esfera pública no Brasil, conforme se pode observar consultando-se o "Cadastro Nacional de Condenações Cíveis por Atos de Improbidade Administrativa", mantido pelo Conselho Nacional de Justiça. Milhares de condenações ali registradas retratam um panorama diferente daquele existente antes do advento da LIA, marcado pela ausência de controle judicial da corrupção e pela quase absoluta impunidade. Embora o problema persista, haja vista a sua natureza sistêmica e endêmica, do que resulta a grande dificuldade no seu desmantelamento (COCKCROFT, 2012, p. 14), o fato é que a Lei significou um avanço no controle da corrupção.

Esse diploma legal, no entanto, não é infensa a críticas. Algumas delas voltadas a aspectos materiais; outras relacionadas a temas processuais. Entre as regras de processo que tem despertado censura está o disposto no $\S 1^{\circ}$ do artigo 17 , que estabelece: “É vedada a transação, acordo ou conciliação nas ações de que trata o caput". Em outras palavras, a LIA veda os aludidos meios de equação de conflitos na ação principal, para a qual estão legitimados ativamente o Ministério Público e a pessoa jurídica interessada.

A questão, no entanto, que mal ou bem parecia pacificada, surgiu com o advento da Medida Provisória n. 703, de 2015, que revogou o referido $\S 1^{\circ}$ do artigo 17 . Ocorre que a aludida Medida Provisória teve a sua vigência encerrada por falta de aprovação, o que acabou por reavivar a mencionada vedação.

Novamente, o problema ressurge com a Resolução n. 179, de 26 de julho de 2017, do Conselho Nacional do Ministério Público (CNMP), que regulamentou o $\S 6^{\circ}$ do artigo $5^{\circ}$ da Lei n. 7.347/1985. Segundo o ato normativo:

É cabível o compromisso de ajustamento de conduta nas hipóteses configuradoras de improbidade administrativa, sem prejuízo do res- 
sarcimento ao erário e da aplicação de uma ou algumas das sanções previstas em lei, de acordo com a conduta ou o ato praticado. (BRASIL, 2017, art. $1^{\circ}, \S 2^{\circ}$ )

A questão, que antes da Medida Provisória n. 703/2005 e da Resolução n. 179/2017-CNMP parecia de simples solução, emerge como problema de significativa complexidade, e, ao mesmo tempo, de grande importância para os operadores do Direito e para a própria sociedade. Com efeito, uma interpretação literal do aludido $\S 1^{\circ}$ do artigo 17 , significa o afastamento dos meios alternativos de solução de conflitos no combate à corrupção; diversamente, a sua aplicação em consonância com a Resolução n. 179/2017-CNMP, importa no reconhecimento de um novo instrumental que, substituindo, em alguns casos, a morosa ação de improbidade administrativa permite a célere solução de conflitos atinentes à prática de corrupção, reconhecida pela sociedade como o maior de seus problemas.

De outra parte, vive-se no Brasil uma verdadeira crise da jurisdição cujo reflexo mais sentido pela população é a falta de uma resposta efetiva do Poder Judiciário num prazo razoável (MORAES, 2014, p. 538-539). Em matéria de defesa do patrimônio público, as ações tramitam vagarosamente, pois para além de uma estrutura judicial aquém das necessidades, o intrincado processo brasileiro atrasa uma resposta judicial definitiva, reforçando a percepção de impunidade e de permanente violação do princípio da moralidade administrativa ${ }^{1}$.

Parte da solução dessa complexa crise passa pela adoção de outros mecanismos de solução de conflitos, como a mediação e a arbitragem. No plano do Ministério Público, destaca-se o controle direto viabilizado por intermédio do inquérito civil, da audiência pública, da recomendação administrativa e do compromisso de ajustamento de conduta (MEDAUR, 2014, p. 179-182). Esse último instrumento foi regulamentado pela Resolução n. 179/2017-CNMP.

O problema central, portanto, consiste no seguinte: é possível a aplicação de outras formas de solução de conflitos em matéria de impro-

${ }^{1}$ Quanto ao teor e ao alcance desse princípio, riquíssima é a lição de Nuno Coelho e Daniel Gonçalves (2016, p. 180-206). 
bidade administrativa, em especial do compromisso de ajustamento de conduta, conforme definido na Resolução do Conselho Nacional do Ministério Público?

A partir de pesquisa bibliográfica e de uma análise sistêmica, empregando-se o método dedutivo, tentar-se-á responder, sob diversos prismas, a esse problema, cujo impacto relativamente à crise da jurisdição e ao enfrentamento da corrupção no Brasil pode ser positivo, dependendo da viabilidade jurídica da incidência da chamada resolutividade em matéria de controle dos atos de improbidade administrativa.

\section{O Poder Regulamentar do Conselho Nacional do Ministério Público}

A atribuição do Ministério Público de promover o inquérito civil e a ação civil pública para a proteção do patrimônio público e social, do meio ambiente e de outros interesses difusos e coletivos é matéria constitucional (art. 129, III), sendo o compromisso de ajustamento de conduta ferramenta de índole legal (art. $5^{\circ}, \S 6^{\circ}$, da Lei n. 7.347/1985) $)^{2}$, posta à disposição dos agentes do Ministério Público ${ }^{3}$. Foi exatamente este o objeto da Resolução 179/2017-CNMP4 .

O poder regulamentar do CNMP é poder de expedição de atos normativos infralegais, o que significa dizer que o Conselho não pode criar direito novo, não pode criar ou revogar norma primária, de atribuição ex-

\footnotetext{
${ }^{2}$ Art. $5^{\circ}[\ldots]:$

$\S 6^{\circ}$ Os órgãos públicos legitimados poderão tomar dos interessados compromisso de ajustamento de sua conduta às exigências legais, mediante cominações, que terá eficácia de título executivo extrajudicial.

${ }^{3}$ Visando à simplificação, no lugar de utilizar toda a nomenclatura que o Direito brasileiro emprega para se referir aos cargos das carreiras dos Ministérios Públicos da União (MP Federal, MP do Trabalho, MP Militar e MP do Distrito Federal e Territórios) e dos Estados, adotar-se-á nesse artigo as expressões genéricas "membros do Ministério Público" ou "agentes do Ministério Público".

${ }^{4}$ Atualmente, esse instrumento de resolução extrajudicial de litígios também encontra previsão no novo Código de Processo Civil (art. 174, inc. III) e na Lei n. 13.140/2015, que previu a autocomposição de conflitos em que for parte pessoa jurídica de Direito Público.
} 
clusiva do Poder Legislativo. Em outros termos, o Conselho Nacional do Ministério Público, no exercício de suas constitucionais atribuições (SILVA, 2014, p. 610-611) $)^{5}$, está autorizado a expedir regulamentos de natureza executiva, que é a modalidade de regulamento permitida em nosso Direito (MELLO, 2014, p. 351-352).

O que o Conselho fez por intermédio da referida Resolução foi regulamentar o aludido dispositivo da Lei de Ação Civil Pública (art. $5^{\circ}, \S$ $6^{\circ}$ ), disciplinando, no âmbito do Ministério Público, a tomada do compromisso de ajustamento de conduta. Não cuidou do tema para todos os legitimados; tratou da matéria exclusivamente para definir, na esfera de atuação dos membros do Ministério Público, como celebrar o termo de ajustamento de conduta, de modo a tornar homogênea e uniforme a atuação dos ramos do Ministério Público da União e dos Ministérios Públicos dos Estados.

Ao editar a Resolução n. 179/2017, o Conselho não criou o compromisso de ajustamento de conduta, não criou direito novo, apenas regulamentou a matéria legal visando a uniformizar o cumprimento dos deveres funcionais dos agentes do Ministério Público nessa seara. Em outras palavras, a Resolução não padece de vício de constitucionalidade ou de legalidade, porquanto somente disciplinou o uso do aludido instrumento legal no âmbito das atribuições ministeriais.

\footnotetext{
${ }^{5}$ Art. 130-A. O Conselho Nacional do Ministério Público compõe-se de quatorze membros nomeados pelo Presidente da República, depois de aprovada a escolha pela maioria absoluta do Senado Federal, para um mandato de dois anos, admitida uma recondução, sendo: $[\ldots]$.

$\S 2^{\circ}$ Compete ao Conselho Nacional do Ministério Público o controle da atuação administrativa e financeira do Ministério Público e do cumprimento dos deveres funcionais de seus membros, cabendo lhe:

I zelar pela autonomia funcional e administrativa do Ministério Público, podendo expedir atos regulamentares, no âmbito de sua competência, ou recomprovidências; [...]
} 


\section{Compromisso de Ajustamento de Conduta: competência, ob- jeto e natureza}

O compromisso de ajustamento de conduta, formalizado por um termo de ajustamento de conduta (TAC), é, segundo o artigo $1^{\circ}$, caput, da Resolução n. 179/2017-CNMP, um “[...] negócio jurídico que tem por finalidade a adequação da conduta às exigências legais e constitucionais, com eficácia de título executivo extrajudicial a partir da celebração [...]”, dispositivo que se harmoniza com o que está previsto na Lei de Ação Civil Pública (art. $5^{\circ}, \S 6^{\circ}$ ).

Além do Ministério Público, podem celebrar compromisso de ajustamento de conduta a Defensoria Pública; a União, os Estados, o Distrito Federal e os Municípios; as autarquias e as fundações públicas. Tais legitimados são daqueles que, "[...] incontroversamente, podem tomar compromisso de ajustamento" (MAZZILLI, 2010, p. 418). As empresas públicas e as sociedades de economia mista que prestam serviços públicos também podem usar desse instrumento (MAZZILLI, 2010, p. 420-421).

As associações civis, pessoas jurídicas exclusivamente de direito privado, por não serem "órgãos públicos" consoante a dicção legal (art. $5^{\circ}, \S 6^{\circ}$ ), não estão legitimadas à celebração de compromisso de ajustamento de conduta. Também não podem os sindicatos e as fundações privadas. A mesma lógica se aplicada às empresas públicas e às sociedades de economia mista exploradoras de atividade econômica, porquanto sujeitas igualmente ao direito privado (art. 173, $\S 1^{\circ}$, inc. II, da CF). Esse conjunto de legitimados para a ação civil pública, "[...] incontroversamente, não podem tomar o compromisso" (MAZZILLI, 2010, p. 419).

Serão compromissários, na assunção das obrigações de fazer, não fazer, indenizar ou mesmo suportar deliberadamente algum tipo de punição, de natureza pecuniária ou obrigacional (multas e proibições), a pessoa física ou jurídica autora da lesão - consumada ou não - a direito difuso, coletivo ou individual homogêneo. Como diz Mazzilli (2010, p. 421), “[...] será o causador do dano ou aquele que possa vir a causá-lo".

A Resolução n. 179/2017-CNMP regulamentou a matéria exclusivamente no âmbito do Ministério Público, tendo atuado o Conselho Na- 
cional nos estritos limites constitucionais e legais de sua competência. Em outras palavras, a Resolução não se aplica aos demais "órgãos públicos".

O compromisso de ajustamento de conduta tem por objeto, em conformidade ao que está disposto no artigo $1^{\circ}$ da Lei n. $7.347 / 1985$, a proteção de direitos ou de interesses difusos, coletivos e individuais homogêneos. Possuem essa natureza coletiva em sentido amplo os direitos concernentes ao meio ambiente (I); ao consumidor (II); a bens e direitos de valor artístico, estético, histórico, turístico e paisagístico (III); a qualquer outro interesse difuso ou coletivo (IV); por infração da ordem econômica (V); à ordem urbanística (VI); à honra e à dignidade de grupos raciais, étnicos ou religiosos (VI); e ao patrimônio público e social (VIII). Essa relação do artigo $1^{\circ}$ da Lei n. 7.347/1985 é meramente exemplificativa, o que significa dizer que caberá a celebração de ajustamento de conduta em outras espécies de direitos ou interesses coletivos não arrolados na Lei de Ação Civil Pública.

Posto que esses direitos não pertencem aos legitimados, não pode o Ministério Público e os demais órgãos públicos na composição levada à efeito com o infrator, fazer concessões que impliquem renúncia total ou parcial dos interesses em jogo. Em outras palavras, o termo de ajustamento de conduta firmado não poderá transacionar com o direito material objeto da composição, o que restou expresso no $\S 1^{\circ}$ do artigo $1^{\circ}$ da Resolução n. 179/2017-CNMP ${ }^{6}$.

O compromisso de ajustamento de conduta tem natureza de título executivo extrajudicial. Essa natureza é conferida ao TAC pela Lei n. $7.347 / 1985$ (art. 5o $\S 6^{\circ}$ ). Segundo Mazzilli (2010, p. 422), o “[...] compromisso de ajustamento de conduta é um título executivo extrajudicial, por meio do qual um órgão público legitimado toma do causador do dano o compromisso de adequar sua conduta às exigências legais".

\footnotetext{
6 "Não sendo o titular dos direitos concretizados no compromisso de ajustamento de conduta, não pode o órgão do Ministério Público fazer concessões que impliquem renúncia aos direitos ou interesses difusos, coletivos e individuais homogêneos, cingindo-se a negociação à interpretação do direito para o caso concreto, à especificação das obrigações adequadas e necessárias, em especial o modo, tempo e lugar de cumprimento, bem como à mitigação, à compensação e à indenização dos danos que não possam ser recuperados".
} 
O órgão público legitimado, mesmo tendo celebrado o compromisso de ajustamento de conduta, pode optar pelo processo de conhecimento visando a obtenção de título executivo judicial. É o que estabelece o Código de Processo Civil ${ }^{7}$.

O compromisso de ajustamento de conduta não é contrato. Como explica Mazzilli (2010, p. 423):

O compromisso de ajustamento de conduta não é um contrato, a uma, porque seu objeto não são direitos patrimoniais de caráter privado; a duas, porque o órgão público que o toma não é titular do direito transindividual nele objetivado, e, como não pode dispor do direito material, não pode fazer concessões quanto ao conteúdo material da lide. Nem se diga que o compromisso teria natureza contratual porque o órgão público nele também assumiria uma obrigação, qual seja a de fiscalizar o seu cumprimento. Essa obrigação não tem caráter contratual, e decorre do poder de polícia da Administração, tanto que, posto omitida qualquer cláusula a respeito no instrumento, mesmo assim subsiste por inteiro o poder de fiscalizar.

Também não é transação, porque esta pressupõe concessões recíprocas relativamente ao direito em jogo, o que não ocorre com o compromisso de ajustamento de conduta.

Embora o compromisso de conduta não vincule o colegitimado que não o celebrou com o autor da lesão, é evidente o impacto do TAC firmado no binômio necessidade/utilidade justificador da propositura da ação civil pública, não podendo tal avença ser desprezada.

Formalizado o compromisso, surge situação jurídica nova, amparada por expressa previsão legal, isto é, o aparecimento de título executivo extrajudicial, fazendo com que deixe de existir o interesse dos colegitimados ativos em obter o provimento jurisdicional condenatório. (VIEIRA, 2015, p. 281-297)

\footnotetext{
${ }^{7}$ Art. 785. A existência de título executivo extrajudicial não impede a parte de optar pelo processo de conhecimento, a fim de obter título executivo judicial.
} 
Tendo havido o compromisso, a ação civil pública "[...] será sempre excepcional, pressupondo a irregularidade da transação" (VIEIRA, 2015, p. 290).

Outro aspecto importante da Resolução do CNMP, é que ela previu em seu artigo $2^{\circ}$ a possibilidade da celebração pelo Ministério Público de compromisso de ajustamento de conduta "para a adoção de medidas provisórias ou definitivas, parciais ou totais".

A celebração de termo de ajustamento de conduta firmado no bojo de inquérito civil ou procedimento administrativo correlato, instaurado por membro do Ministério Público, deve envolver a participação do Conselho Superior do Ministério Público (art. $6^{\circ}$ da Resolução n. 179/2017CNMP). Essa atuação, entretanto, deverá ser regulada pelo Conselho Superior de cada Ministério Público, conforme dispõe a Lei n. 7.347/1985 ${ }^{8}$.

\section{Compromisso de Ajustamento de Conduta em Inquérito Civil que Investiga Improbidade}

Pende dúvida acerca da possibilidade de celebração de compromisso de ajustamento de conduta quando o objeto do inquérito civil consiste na investigação da prática de ato de improbidade administrativa. O problema decorre do já referido $\S 1^{\circ}$ do artigo 17 da Lei n. 8.429/1992, que veda a transação, acordo ou conciliação nas ações de improbidade administrativa. Tal dispositivo recebeu interpretação rigorosa da doutrina. É o que retrata a lição de Wallace Paiva Martins Júnior (2001, p. 312):

Em se tratando de probidade administrativa, a natureza do interesse em particular não permite renúncia a qualquer dos provimentos típicos previstos, pois a indisponibilidade daí derivada é absoluta.

\footnotetext{
${ }^{8}$ Art. $9^{\circ}$ Se o órgão do Ministério Público, esgotadas todas as diligências, se convencer da inexistência de fundamento para a propositura da ação civil, promoverá o arquivamento dos autos do inquérito civil ou das peças informativas, fazendo-o fundamentadamente. $[\ldots]$.

$\S 3^{\circ}$ A promoção de arquivamento será submetida a exame e deliberação do Conselho Superior do Ministério Público, conforme dispuser o seu Regimento.
} 
As sanções são irrenunciáveis e indisponíveis, não admitindo transação, composição ou acordo, que, se realizados, são absolutamente nulos, e esse traço reforça o entendimento da cumulatividade das sanções. Os co-legitimados ativos do art. 17 não tem disponibilidade sobre o patrimônio público ou sobre a moralidade administrativa. Igualmente, não é admissível a desistência da ação proposta ${ }^{9}$.

Esse tipo de compreensão expandiu o alcance do dispositivo para um grau máximo, a ponto de surpreender os próprios doutrinadores, como é o caso de Carlos Frederico Brito dos Santos (2007, p. 255):

Concordaríamos com a medida radical tomada pelo legislador se o conceito de ato de improbidade administrativa se restringisse ao art. $9^{\circ}$ e à hipótese de violação do dever de honestidade contida no art. 11 da lei comentada. Contudo, como a referida conceituação abrange inclusive a hipótese de dano culposo ao erário, entendemos que a razoabilidade indica que teria sido melhor que a vedação fosse estabelecida como regra, excepcionando as hipóteses dos arts. $10 \mathrm{e}$ 11 , neste último dispositivo desde que o ato improbo não decorresse da desonestidade do agente público. Afinal, se a plea bargaining é uma tendência no próprio Direito Penal, que apesar de lidar com o "mínimo do mínimo ético" busca alternativas para as penas restritivas da liberdade de locomoção, não vislumbramos maiores razões que desaconselhem - de lege ferenda - a adoção tanto da transação judicial quanto do compromisso de ajustamento em sede de improbidade administrativa, desde que adotadas as devidas cautelas legislativas para a garantia da sua eficácia.

Embora a transação judicial exija a reforma da Lei n. 8.429/1992 para ser admitida, como menciona a citada lição, o compromisso de ajustamento de conduta parece não carecer de nova lei para o seu emprego no âmbito da improbidade administrativa. Com efeito, o problema parece residir no fato de que o $\S 1^{\circ}$ do artigo 17 da LIA vem sendo tratado como

\footnotetext{
${ }_{9}^{9}$ No mesmo sentido: Marino Pazzaglini Filho (2011, p. 209); Carlos Frederico Brito dos Santos (2007, p. 254-255), com ressalvas, pois, para ele, a lei deveria ter excepcionado o "dano culposo ao erário"; e Marcelo Figueiredo (2000, p. 234-235), que igualmente aponta o excessivo rigor da norma.
} 
norma de direito material, de natureza absoluta, ligada ao Direito Administrativo, e não como regra de Direito Processual Civil.

Como regra de direito material, esse $\S 1^{\circ}$ parece ter sido interpretado como resultante do princípio da indisponibilidade do interesse público, de maneira que o operador do direito é obrigado, sempre, presentes os indícios, a propor a ação civil pública por ato de improbidade administrativa, na busca de uma sentença judicial reconhecendo a prática de ato de improbidade administrativa. Essa doutrina, sob o prisma do Direito Administrativo, tornou a ação civil pública por ato de improbidade administrativa obrigatória ${ }^{10}$, o que levou, consequentemente, à compreensão no sentido da inaplicabilidade do compromisso de ajustamento de conduta na fase de investigação, pois, por óbvio, se a ação de improbidade é indispensável, não seria crível a celebração de TAC no inquérito civil, ou a aplicação de qualquer outra técnica de solução extrajudicial de conflito nessa matéria.

Mesmo sob o prisma material, essa compreensão é demasiadamente rigorosa, pois, a Lei n. 8.429/1992 veda a transação, acordo ou conciliação ${ }^{11}$, mas não proíbe o compromisso de ajustamento de conduta, que é coisa diversa.

Embora não se negue a natureza de negócio jurídico de todas essas modalidades de composição, há uma diferença fundamental entre as três primeiras, com assento no $\S 1^{\circ}$ do artigo 17 da Lei n. 8.429/1992, e a última, com previsão no $\S 6^{\circ}$ do artigo $5^{\circ}$ da Lei n. 7.347/1985: na tran-

\footnotetext{
${ }^{10}$ Para Emerson Garcia e Rogério Pacheco Alves (2017, p. 932-933), vigora o princípio da obrigatoriedade: “[...] defendemos a incidência do princípio da obrigatoriedade no campo dos interesses difusos, obrigatoriedade tanto quanto à deflagração do procedimento investigatório quanto, por evidente, ao ajuizamento da ação civil pública".

${ }^{11}$ Eduardo Cambi e Cláudio Diniz (2017) entendem, de forma excepcional, possível a transação em matéria de improbidade administrativa: “[...] em circunstâncias excepcionais, desde que rigorosamente motivadas, sempre sujeitas ao criterioso e prévio controle dos órgãos colegiados, há possibilidade de transação, nas hipóteses em que restar demonstrado que a disposição quanto a certas sanções venha a se revelar mais consentânea com a proteção do bem jurídico tutelado".
} 
sação ${ }^{12}$, no acordo ${ }^{13}$ ou na conciliação ${ }^{14}$ está explícita ou implícita a ideia de concessão recíproca entre as partes e de renúncia a direito material; no compromisso de ajustamento de conduta não há concessão ou renúncia a direito material, conforme restou definido na Resolução n. 179/2017CNMP. Nesta última modalidade, há ajuste somente quanto à forma de recomposição do bem jurídico lesado. Demais disso, é título executivo extrajudicial.

Não se pode, no plano do direito material, confundir transação, acordo ou conciliação com compromisso de ajustamento de conduta. Se aquelas modalidades de negócio jurídico do $\S 1^{\circ}$ do artigo 17 podem ferir o princípio da indisponibilidade do interesse público, essa ofensa inexiste na esfera do compromisso de ajustamento de conduta, que apenas estabelece um procedimento para a integral preservação ou recomposição do bem lesado diante do caso concreto. Logo, mesmo na perspectiva do Direito Administrativo, é admissível a celebração de compromisso de ajustamento de conduta em matéria de improbidade administrativa na fase do inquérito civil, pois o interesse público em jogo não é disponibilizado, inexistindo renúncia a direito no TAC destinado a fazer valer as exigências da Lei n. 8.429/1992.

A celebração de compromisso de ajustamento de conduta nos casos de improbidade administrativa demanda especial atenção no que tange à

12 “Transação. No conceito do Direito Civil, no entanto, e como expressão usada em sentido estrito, transação é a convenção em que, mediante concessões recíprocas, duas ou mais pessoas ajustam certas cláusulas e condições para que previnam litígio, que se possa suscitar entre elas, ou ponham fim a litígio já suscitado.” (SILVA, 1984, p. 403)

13 "Acordo. Condições ajustadas entre duas ou mais pessoas no intuito de fazer cessar uma pendência ou uma demanda. O instrumento em que se firma essa convenção". (SILVA, 1984, p. 77)

14 "Conciliação. Derivado do latim conciliatio, de conciliare (atrair, harmonizar, ajuntar), entende-se o ato pelo qual duas ou mais pessoas desavindas a respeito de certo negócio, ponham fim à divergência amigavelmente. Está, assim, na conformidade de seu sentido originário, de harmonização a respeito do que se diverge”. (SILVA, 1984, p. 486-487) 
correta aplicação dos princípios da proporcionalidade ${ }^{15}$, razoabilidade ${ }^{16}$ e eficiência ${ }^{17}$, sendo recomendada essa forma de autocomposição para os casos de menor potencial ofensivo, embora a Resolução n. 179/2017CNMP nada tenha dito a esse respeito ${ }^{18}$. O compromisso de ajustamento de conduta cumpre com os aludidos parâmetros normativos, nas hipóteses em que as sanções de perda do cargo e ou de suspensão dos direitos políticos, que exigem sentença judicial para a sua aplicação (art. 20 da Lei n. $8.429 / 1992)^{19}$, se mostrem concretamente inadequadas.

Se a gravidade dos atos de improbidade administrativa praticados exigirem a aplicação das aludidas medidas, não existirá outra opção ao membro do Ministério Público, que haverá de propor a ação de improbidade na busca de uma sentença que aplique as sanções de perda do cargo e de suspensão dos direitos políticos. Esse parece ser um critério importante para se definir a viabilidade ou não de celebração de TAC em matéria de improbidade administrativa, a ser considerado pelo próprio agente do Ministério Público ou pelo Conselho Superior do Ministério Público,

15 "Este princípio enuncia a ideia - singela, aliás, conquanto frequentemente desconsiderada - de que as competências administrativas só podem ser validamente exercidas na extensão e intensidade correspondentes ao que seja realmente demandado para o cumprimento da finalidade de interesse público a que estão atreladas”. (MELLO, 2014, p. 113)

16 "Enuncia-se com o princípio que a Administração, ao atuar no exercício de discrição, terá de obedecer a critérios aceitáveis do ponto de vista racional, em sintonia com o senso normal de pessoas equilibradas e respeitosas das finalidades que presidiram a outorga da competência exercida”. (MELLO, 2014, p. 111)

${ }^{17}$ Como leciona Odete Medauar (2014, p. 148), “[...] o princípio da eficiência determina que a Administração deve agir, de modo rápido e preciso, para produzir resultados que satisfaçam as necessidades da população" .

${ }^{18}$ O Ministério Público do Estado do Paraná, antes do advento do ato do CNMP, editou a Resolução n. 01/2017 PGJ-CSMP, que estabelece parâmetros procedimentais e materiais a serem observados para a celebração de composição, nas modalidades compromisso de ajustamento de conduta e acordo de leniência, envolvendo as sanções cominadas aos atos de improbidade administrativa, definidos na Lei n. 8.429, de 2 de junho de 1992, e aos atos praticados contra a Administração Pública, definidos na Lei n. 12.846 , de $1^{\circ}$ de agosto de 2013, aplicável no âmbito do Ministério Público do Estado do Paraná. O ato do MPPR restringiu o compromisso de ajustamento de conduta aos casos de improbidade administrativa de menor potencial ofensivo.

${ }^{19}$ Art. 20. A perda da função pública e a suspensão dos direitos políticos só se efetivam com o trânsito em julgado da sentença condenatória. 
nesse caso, visando a homologação - ou não - do arquivamento do inquérito civil.

Um outro critério para essa definição reside na autonomia funcional, pois mesmo nas hipóteses em que o compromisso seja viável, o agente do Ministério Público poderá optar por investigar e propor a ação de improbidade, na busca de um título judicial. Em outros termos, o investigado não tem o direito subjetivo à celebração do compromisso de ajustamento de conduta.

O compromisso caberá nos casos em que as sanções de natureza pecuniária ou econômica previstas no artigo 12 da Lei n. 8.429/1992 forem suficientes para uma efetiva resposta, para a prevenção e repressão do ímprobo comportamento. Têm essa natureza as seguintes medidas: ressarcimento integral do dano (1), perda dos bens ou valores acrescidos ilicitamente ao patrimônio (2), multa civil (3) e proibição de contratar com o Poder Público ou receber benefícios ou incentivos fiscais ou creditícios, direta ou indiretamente, ainda que por intermédio de pessoa jurídica da qual seja sócio majoritário (4) (BERTONCINI, 2007, p. 241-243). Relativamente a elas, por serem sanções de natureza eminentemente civil, vigoram os princípios da autonomia da vontade e da disponibilidade, nada impedindo que o investigado firme compromisso de ajustamento de conduta aceitando-as livremente e assumindo executá-las.

Outro argumento de índole material refere-se à natureza não absoluta do princípio da indisponibilidade do interesse público, que pode ser temperado ou, em alguns casos, relativizado pela lei - direito de regras -, de modo a excepcionar o princípio e, também, pela circunstância de inexistirem direitos absolutos. Como leciona Celso Antônio Bandeira de Mello, ao tratar do conteúdo do regime jurídico-administrativo:

Todos os princípios expostos e que se apresentam como decorrências sucessivas, uns dos outros, sofrem, evidentemente, limitações e temperamentos e, como é óbvio, têm lugar na conformidade do sistema normativo, segundo seus limites e condições, respeitados os direitos adquiridos e atendidas as finalidades contempladas em as (sic) normas que os consagram. (MELLO, 2014, p. 75) 
O exemplo de que a lei pode ser empregada para excepcionar a indisponibilidade do interesse público reside na própria história do $\S 1^{\circ}$ do artigo 17 da Lei de Improbidade Administrativa, temporariamente suspenso pela Medida Provisória n. 703/2015 que, por falta de aprovação, perdeu sua força normativa e reavivou a disposição referida. Outro exemplo é a Lei n. 12.846/2013, que prevê o acordo de leniência celebrado com a pessoa jurídica autora de ato lesivo à administração pública, isentando-a de sanção ou reduzindo-as ${ }^{20}$. A Lei n. 12.529/2011, que estrutura o Sistema Brasileiro de Defesa da Concorrência, em seu artigo 86, permite a celebração de acordo de leniência com pessoas físicas e jurídicas que forem autoras de infração à ordem econômica, desde que colaborem efetivamente com as investigações e o processo administrativo ${ }^{21}$. De igual sorte, a lei excepciona o princípio da indisponibilidade do interesse público e a obrigatoriedade da ação penal pública, quando prevê a colaboração premiada como meio de obtenção de prova na seara criminal (Lei n. 12.850/2013).

De outra parte, a aplicação de princípios não se dá mediante o tudo ou nada das regras, mas a partir do balanceamento dos valores e interesses que estão em jogo em um dado caso concreto. Não há sentido, por exemplo, que o Estado gaste milhares de reais com juízes, promotores, servidores do Judiciário e do Ministério Público, para processar por ato de improbidade administrativa um servidor que cometeu um pequeno peculato. Os princípios da razoabilidade e da proporcionalidade aplicados

\footnotetext{
${ }^{20}$ Art. 16. A autoridade máxima de cada órgão ou entidade pública poderá celebrar acordo de leniência com as pessoas jurídicas responsáveis pela prática dos atos previstos nesta Lei que colaborem efetivamente com as investigações e o processo administrativo, sendo que dessa colaboração resulte:

$\S 2^{\circ}$ A celebração do acordo de leniência isentará a pessoa jurídica das sanções previstas no inciso II do art. $6^{\circ}$ e no inciso IV do art. 19 e reduzirá em até 2/3 (dois terços) o valor da multa aplicável.

${ }^{21}$ Art. 86. O Cade, por intermédio da Superintendência-Geral, poderá celebrar acordo de leniência, com a extinção da ação punitiva da administração pública ou a redução de 1 (um) a 2/3 (dois terços) da penalidade aplicável, nos termos deste artigo, com pessoas físicas e jurídicas que forem autoras de infração à ordem econômica, desde que colaborem efetivamente com as investigações e o processo administrativo e que dessa colaboração resulte: $[\ldots]$.
} 
a casos como esse indicam que um termo de ajustamento de conduta já seria suficiente para equacionar problema tão modesto, não havendo justificativa (necessidade/utilidade) para uma ação de improbidade administrativa.

Demais disso, a atuação do Ministério Público não pode ser incoerente e disfuncional. Ao mesmo tempo em que dá curso à persecução criminal, necessita agir na esfera cível em matéria de defesa do patrimônio público, inclusive no que tange à Lei n. 8.429/1992 e à Lei n. 12.846/2013, evidentemente de modo harmônico. Não há sentido em o MP firmar acordo de colaboração premiada, não oferecendo denúncia contra um determinado réu por crime da Lei de Licitações e Contratos Administrativos (Lei n. 8.666/1993), mas, no entanto, processar a mesma pessoa por improbidade administrativa, haja vista a exagerada compreensão do $\S 1^{\circ}$ do artigo 17 da Lei n. 8.429/1992. Há que se fazer a interpretação da LIA a partir da CF e do microssistema da qual faz parte, e não uma análise gramatical, isolada e absoluta do dispositivo.

A celebração de compromisso de ajustamento de conduta no âmbito da improbidade administrativa se razoável, proporcional e eficiente no caso concreto, não afeta o princípio da indisponibilidade do interesse público, ao contrário, melhor o representa. Em que pese o $\S 1^{\circ}$ do artigo 17 da LIA não ser norma de Direito Administrativo, ainda que interpretado à luz do princípio da indisponibilidade do interesse público, o dispositivo não tem a abrangência que lhe é atribuída por parcela da doutrina.

Noutro giro, parece mais adequado se entender que o $\S 1^{\circ}$ do artigo 17 da Lei n. 8.429/1992 é norma de processo. O artigo cuida exclusivamente da ação principal, que terá o rito ordinário, e que poderá ser proposta pelo Ministério Público ou pela pessoa jurídica interessada, dentro de trinta dias da efetivação da medida cautelar. Todos os parágrafos contidos nesse artigo, em número de treze, cuidam de aspectos processuais relacionados à ação civil pública por ato de improbidade administrativa, como a intervenção do Ministério Público como fiscal da lei, se ele não for o autor; a prevenção do juízo; a notificação do requerido; a rejeição da ação; o recebimento da inicial; o recurso contra o recebimento etc. Esse 
artigo está contido no Capítulo V, que trata do procedimento administrativo e do processo judicial.

Seja na exclusiva perspectiva do artigo 17 sob análise, do capítulo a que pertence ou do inteiro teor da Lei n. 8.429/1992, não há uma única referência ao inquérito civil, o que permite afirmar que o $\S 1^{\circ}$ do artigo 17 não incide relativamente a esse procedimento administrativo de investigação. Portanto, não é exagero afirmar-se que o dispositivo há de ser compreendido nos limites de suas forças, ou seja, exclusivamente em relação à ação principal de que trata, ao capítulo que pertence e ao diploma que integra. Como dito, a Lei de Improbidade Administrativa não faz qualquer referência ao inquérito civil, categoria com previsão em outro diploma normativo; e também não alude ao compromisso de ajustamento de conduta. Ambas as leis - LIA e LACP - merecem ser harmonizadas tendo em conta o microssistema que integram.

O inquérito civil está previsto na Constituição de 1988 (art. 129, inc. III) e na Lei n. 7.347/1985. Encontra-se sujeito a um regime jurídico distinto da ação civil pública por ato de improbidade administrativa. Noutros termos, o $\S 1^{\circ}$ do artigo 17, sendo norma de processo civil, tem alcance bem definido, não se aplicando à fase de investigação do ato de improbidade administrativa, enfim, ao inquérito civil.

A essa ferramenta de investigação não se aplica o óbice da Lei n. 8.429/1992 que, repita-se, não veda a utilização do compromisso de ajustamento de conduta. Esse compromisso, com expressa previsão no $\S 6^{\circ}$ do artigo $5^{\circ}$ da Lei n. 7.347/1985, não sofre com a multicitada restrição.

Em sendo aplicável a celebração desse tipo de compromisso no inquérito civil, esse ajuste deve importar no ressarcimento integral do dano, se houver, o mesmo podendo dizer-se em relação à perda dos bens ou valores acrescidos ilicitamente ao patrimônio, medidas obrigatórias segundo a Lei n. 8.429/1992 22 . Há, ainda, a necessidade da aplicação de uma ou mais sanções, segundo os termos da Resolução do CNMP, excluídas

\footnotetext{
${ }^{22}$ Art. $5^{\circ}$. Ocorrendo lesão ao patrimônio público por ação ou omissão, dolosa ou culposa, do agente ou de terceiro, dar-se-á o integral ressarcimento do dano. Art. $6^{\circ}$. No caso de enriquecimento ilícito, perderá o agente público ou terceiro beneficiário os bens ou valores acrescidos ao seu patrimônio.
} 
aquelas que exigem sentença transitada em julgado para a sua aplicação, ou seja, a perda do cargo e a suspensão dos direitos políticos. Não se pode esquecer que as sanções de natureza civil da LIA integram a esfera de disponibilidade do investigado.

Nessa perspectiva, é possível se afirmar que é juridicamente adequada a regulamentação do $\S 6^{\circ}$ do artigo $5^{\circ}$ da Lei n. 7.347 pelo Conselho Nacional do Ministério Público.

\section{Compromisso de Ajustamento de Conduta na ação de Impro- bidade Administrativa}

A utilização do compromisso de ajustamento de conduta no âmbito do Ministério Público está relacionada a um procedimento administrativo investigatório, normalmente o inquérito civil. É necessário se fazer esse recorte, pois o inquérito civil, como visto, é procedimento inquisitorial posto à disposição do Ministério Público, mediante o qual o seu agente investiga e obtém os indícios mínimos necessários da ocorrência da lesão ou de ameaça de lesão a direito difuso, coletivo ou individual homogêneo. Nesse caso, o membro do Ministério Público haverá de optar por um dos seguintes caminhos: a) propor a ação civil pública; b) firmar o TAC visando ao atendimento das exigências do ordenamento jurídico.

A ideia de que o compromisso de ajustamento de conduta precede a propositura da ação civil pública está relacionada à natureza de título executivo extrajudicial dessa modalidade de negócio jurídico. Em outras palavras, celebra-se o compromisso para se evitar a judicialização, recorrendo-se ao Poder Judiciário em caso de descumprimento deste, via ação executiva.

Ocorre, no entanto, como regra, que inexiste impedimento legal para a celebração de avença no curso da ação. O que significa dizer que requerente e requerido podem propor ao Poder Judiciário pôr termo ao processo, mediante a celebração de negócio jurídico que demandará, no entanto, o conhecimento pelo juízo e a eventual homologação judicial por sentença, realizando juiz "atividade jurisdicional típica". 
A decisão homologatória (de transação, renúncia ou reconhecimento jurídico do pedido, bem como de outro meio consensual de solução de controvérsias) é de mérito (cf. art. 487, III, do CPC/2015). Ao homologar atos autocompositivos manifestados pelas partes, o juiz realiza atividade jurisdicional típica: a jurisdição tem por função, além de julgar o pedido, também de promover a solução da lide através de meios consensuais. Diante disso, não se pode dizer que o juiz, ao "homologar" acordo de vontade entre as partes, realiza algo atípico, impróprio ou anormal. (MEDINA, 2016, p. 765)

No entanto, especificamente em relação à ação de improbidade, é vedada a transação, acordo ou conciliação. Afora essas hipóteses - que deverão ser rejeitadas pelo Poder Judiciário -, as partes podem acordar quanto ao reconhecimento jurídico do pedido, nos termos do artigo 487, inc. III, alínea "a", do Código de Processo Civil.

Nesse caso, a rigor, não se estará diante de um verdadeiro compromisso de ajustamento de conduta, embora a Resolução n. 179/2017CNMP tenha se utilizado dessa expressão. Com efeito, o reconhecimento da procedência do pedido firmado entre as partes por meio de um TAC, não representa negócio jurídico fruto da autocomposição entre o Ministério Público e o compromitente já processado judicialmente por ato de improbidade administrativa, posto que esse reconhecimento nem mesmo demandaria a celebração de TAC, porquanto poderia ser levado a efeito de forma unilateral pelo interessado, independentemente da anuência do Ministério Público. Além disso, posto que firmado já na fase judicial, perde sua natureza de título executivo extrajudicial, demandando esse reconhecimento da procedência do pedido sentença homologatória para a produção de efeitos.

Nessa perspectiva, parece equivocada a iniciativa do Conselho Nacional do Ministério Público de disciplinar, no âmbito do Ministério Público, a tomada do compromisso de ajustamento de conduta na fase judicial, "no curso da ação judicial", consoante o artigo $3^{\circ}$, caput, da Resolução n. 179/2017²3.

23 "O compromisso de ajustamento de conduta será tomado em qualquer fase da investigação, nos autos de inquérito civil ou procedimento correlato, ou no curso da ação 
Essa expressão "ou no curso da ação judicial” é ilegal, pois contrária ao artigo 487, inciso III, letra "a", do CPC, e ao próprio artigo $5^{\circ}, \S 6^{\circ}$, da Lei n. 7.347/1985, que estabelece que o TAC é título executivo extrajudicial e, portanto, só pode ser firmado antes da propositura da ação civil pública. Em outros termos, judicializada a questão esgota-se a atribuição do membro do Ministério Público de realizar a tomada de compromisso de ajustamento de conduta. Ao não respeitar esse limite, a Resolução, no aludido ponto, editou norma de processo civil, o que é defeso ao CNMP fazer, haja vista o que dispõe o inciso I do artigo $22 \mathrm{da} \mathrm{CF}$.

Em síntese, não é possível a celebração de compromisso de ajustamento de conduta após a propositura da ação de improbidade administrativa.

\section{Transação, Acordo ou Conciliação nas Ações de Improbidade Administrativa}

$\mathrm{O} \S 1^{\circ}$ do artigo 17 da Lei de Improbidade Administrativa peremptoriamente determina que: "É vedada a transação, acordo ou conciliação nas ações de que trata o caput".

Esse dispositivo foi temporariamente revogado pela Medida Provisória $n$. 703/2015, o que significa dizer que, a princípio, durante certo período de tempo, o da vigência da Medida Provisória, foi possível a celebração de transação, acordo ou conciliação nas ações civis públicas por ato de improbidade administrativa. Ocorre que essa Medida Provisória não foi aprovada a tempo pelo Congresso Nacional, e por isso teve a sua vigência encerrada, reavivando a referida vedação.

Embora não se ignore a pertinência de uma futura alteração legislativa que venha a permitir a celebração de transação, acordo ou conciliação nas ações civis públicas por ato de improbidade administrativa, o fato é que a norma vige e por isso deve ser respeitada no seu estrito âmbito de incidência. $\mathrm{O}$ combate à corrupção, problema global de natureza eco-

judicial, devendo conter obrigações certas, líquidas e exigíveis, salvo peculiaridades do caso concreto, e ser assinado pelo órgão do Ministério Público e pelo compromissário". 
nômica, cultural e política (ROSE-ACKERMAN; PALIFKA, 2016), depende para a sua efetividade do respeito à lei como expressão do Estado Democrático de Direito.

\section{Conclusão}

A título de conclusão, parece correto se afirmar que a crise da jurisdição vivida no Brasil está longe de uma solução adequada, posto não depender exclusivamente do Poder Judiciário, embora não se negue que uma parcela dos problemas possa ser resolvida pelo próprio sistema judicial. Essa crise impacta no combate à corrupção, no enfrentamento dos atos de improbidade administrativa, porquanto atrasa sobremaneira o seu controle judicial, gerando forte sentimento de impunidade. Como assevera Alexandre de Moraes (2014):

Se a demora nas decisões é inconcebivel, por retardar a Justiça aos cidadãos; a demora na regulamentação das normas constitucionais, que afasta os cidadãos de seus direitos; ou mesmo, a demora administrativa na implementação dos diversos direitos sociais. O problema, portanto, é estrutural e conjuntural, e não somente do Poder Judiciário, que, por sua vez, deve obrigatoriamente, modernizar a prestação da atividade jurisdicional, adaptando-se aos novos tempos sem perder sua autonomia [...]. A modernização, porém, não depende somente do Poder Judiciário [...]

Na linha da ideologia do novo Código de Processo Civil, é essencial que se adote e se utilize gradativamente outras formas de solução de controvérsias, envolvendo a atuação de instituições e órgãos públicos, que devem se colocar à disposição do cidadão e da sociedade para a adoção de um comportamento resolutivo, no lugar da preservação de uma atuação burocrática e demandista, cujo maior efeito não foi a solução dos conflitos individuais e coletivos, mas o verdadeiro entupimento das vias judiciais pelo excesso de processos, gerando a aludida crise da jurisdição que a todos prejudica. 
Embora a solução desse complexo problema não dependa exclusivamente do Poder Judiciário, como já foi afirmado, é também possível se dizer que, em parte, o próprio Poder Judiciário e as Instituições essenciais à Justiça podem contribuir para a sua redução viabilizando a implementação de outras formas de solução de conflitos, naturalmente respeitados os limites do Estado de Direito.

Imbuído desse propósito, o Conselho Nacional do Ministério Público editou a Resolução n. 179/2017, para regulamentar o compromisso de ajustamento de conduta no âmbito do Ministério Público. Objeto dessa pesquisa, ao fim e ao cabo, parece possível se concluir que:

$1^{\mathrm{a}}$ - O Conselho Nacional do Ministério Público pode regulamentar o compromisso de ajustamento de conduta, na medida em que ao fazê-lo age no exercício de seu poder regulamentar.

$2^{\mathrm{a}}$ - Trata-se o compromisso de ajustamento de conduta de negócio jurídico sujeito a um regime jurídico especial, que impede a autoridade pública celebrante de fazer concessões que impliquem renúncia aos interesses difusos, coletivos e individuais homogêneos, regulando em especial o modo, tempo e lugar do cumprimento do avençado.

$3^{\mathrm{a}}-$ É possível a celebração de compromisso de ajustamento de conduta no inquérito civil que investiga atos de improbidade administrativa, pois esse tipo de negócio jurídico, apesar da proximidade, não se confunde com a transação, acordo ou conciliação; também porque o inquérito civil não é alcançado pela vedação contida no artigo $17, \S 1^{\circ}$, da Lei $n$. 8.429/1992, sendo tal disposição norma de direito processual civil.

$4^{\mathrm{a}}$ - Não é possível a celebração de compromisso de ajustamento de conduta na ação de improbidade administrativa, porquanto o TAC é título executivo extrajudicial, não podendo ser firmado no curso da ação; nada impede, no entanto, que o Ministério Público e o requerido celebrem ajuste no qual o suplicado reconheça a procedência do pedido, o que, no entanto, exigirá homologação por sentença judicial (art. 487, inc. III, letra "a", do CPC).

$5^{a}$ - Não é possível a transação, acordo ou conciliação nas ações de improbidade administrativa, diante de expressa vedação legal. 
Em outros termos, parece adequado se afirmar a incidência de outras formas de solução de conflitos nas hipóteses configuradoras de improbidade administrativa, em especial, o compromisso de ajustamento de conduta, tomado em qualquer fase da investigação, nos autos de inquérito civil ou procedimento correlato, nos termos da Resolução n. 179/2017CNMP. No entanto, não se apresenta juridicamente aceitável a sua tomada no curso da ação judicial, porquanto, nesse caso, estar-se-á diante de categoria jurídica diversa.

Em síntese, a resolutividade via TAC pode contribuir para amenizar a crise da jurisdição no Brasil e o enfrentamento da corrupção, mal que aflige sobremaneira a população brasileira, sem se olvidar de que esse problema é, de fato, um problema mundial, que afeta muitos povos e nações (COCKCROFT, 2012).

\section{Referências}

BERTONCINI, Mateus. Ato de Improbidade Administrativa. São Paulo: Editora Revista dos Tribunais, 2007.

BRASIL. Constituição (1988). Constituição da República Federativa do Brasil. Texto constitucional promulgado em 5 de outubro de 1988, com as alterações adotadas pelas Emendas Constitucionais. Disponível em: <https://goo.gl/zaRrL>. Acesso em: 5 dez. 2017.

. Congresso Nacional. Lei n. 8.429, de 2 de junho de 1992. Disponível em: <https://goo.gl/JWCMf>. Acesso em: 6 dez. 2017. . Presidência da República. Medida Provisória n. 703, de 30 de dezembro de 2004. Altera a Lei n. 12.846, de $1^{\circ}$ de agosto de 2013, para dispor sobre acordos de leniência. Disponível em: $<$ https://goo.gl/ nqwhdi>. Acesso em: 5 dez. 2017.

. Congresso Nacional. Lei n. 12.529, de 30 de novembro de 2011. Disponível em: <https://goo.gl/rZvtLP>. Acesso em: 5 dez. 2017. . Congresso Nacional. Lei n. 12.846, de $1^{\text {o }}$ de agosto de 2013. Disponível em: <https://goo.gl/XytIot>. Acesso em: 5 dez. 2017. 
. Congresso Federal. Lei n. 12.850, de 2 de agosto de 2013. Disponível em: <https://goo.gl/4sweKB>. Acesso em: 5 dez. 2017.

. Congresso Federal. Lei n. 13.105, de 16 de março de 2015. Institui o Código de Processo Civil. Disponível em: $<$ https://goo. gl/6b0EbE >. Acesso em: 5 dez. 2017.

. Conselho Nacional do Ministério Público (CNMP). Resolução n. 179, de 26 de julho de 2017. Regulamenta o $\S 6^{\circ}$ do art. $5^{\circ}$ da Lei $n$. 7.347/1985, disciplinando, no âmbito do Ministério Público, a tomada do compromisso de ajustamento de conduta. Disponível em: $<$ https://goo.gl/ Sq4aq5 >. Acesso em: 5 dez. 2017.

CAMBI, Eduardo; DINIZ, Cláudio Smirne. Possibilidades de solução extrajudicial de conflitos na área da proteção ao patrimônio público e da tutela da probidade administrativa. Tese Aprovada no XXII Congresso Nacional do Ministério Público, ocorrido em Belo Horizonte, em setembro de 2017. Disponível em: <https:/goo.gl/uc5831>. Acesso em: 5 dez. 2017.

COCKCROF, Laurence. Global Corruption: Money, Power and Ethics in the Modern World. London: I.B. Tauris \& Co. Ltd., 2012.

COELHO, Nuno Manuel Morgadinho dos Santos; GONÇALVES, Daniel Diniz. Moralidade administrativa: uma construção hermenêutica. Revista Jurídica, Curitiba, v. 4, n. 45, p. 180-206, 2016. Disponível em: $<$ https:// goo.gl/XzTQEd>. Acesso em: 24 nov. 2017.

GARCIA, Emerson; ALVES, Rogério Pacheco. Improbidade administrativa. 9. ed. São Paulo: Editora Saraiva, 2017.

FAZZIO JÚNIOR, Waldo. Improbidade administrativa: doutrina, legislação e jurisprudência. 3. ed. São Paulo: Editora Atlas, 2015.

FIGUEIREDO, Marcelo. Probidade Administrativa: Comentários à Lei n. 8.429/92 e legislação complementar. 4. ed., revista, atualizada e ampliada. São Paulo: Malheiros Editores, 2000.

MARTINS JÚNIOR, Wallace Paiva. Probidade Administrativa. São Paulo: Editora Saraiva, 2001. 
MAZZILI, Hugo Nigro. A defesa dos interesses difusos em juízo: meio ambiente, consumidor, patrimônio cultural, patrimônio público e outros interesses. 23. ed. São Paulo: Editora Saraiva, 2010.

MEDAUR, Odete. Controle da Administração Pública. 3. ed. São Paulo: Editora Revista dos Tribunais, 2014.

. Direito Administrativo Moderno. 18. ed. São Paulo: Editora Revista dos Tribunais, 2014.

MEDINA, José Miguel Garcia. Novo Código de Processo Civil Comentado. 4. ed. São Paulo: Editora Revista dos Tribunais, 2016. MELLO, Celso Antônio Bandeira de. Curso de Direito Administrativo. 32. ed. São Paulo: Malheiros Editores, 2014.

MORAES, Alexandre de. Direito Constitucional. 30. ed. São Paulo: Editora Atlas, 2014.

PARANÁ. Conselho Superior do Ministério Púbico do Estado do Paraná. Resolução n. 01, de 15 de maio de 2017. Estabelece parâmetros procedimentais e materiais a serem observados para a celebração de composição, nas modalidades compromisso de ajustamento de conduta e acordo de leniência, envolvendo as sanções cominadas aos atos de improbidade administrativa, definidos na Lei n. 8.429, de 02.06.1992, e aos atos praticados contra a Administração Pública, definidos na Lei n. 12.846, de 01.08.2013, no âmbito do Ministério Público do Estado do Paraná. Disponível em: <https://goo.gl/F6G8x6>. Acesso em: 5 dez. 2017.

\section{PAZZAGLINI FILHO, Marino. Lei de Improbidade Administrativa}

Comentada: aspectos constitucionais, administrativos, civis, criminais, processuais e de responsabilidade fiscal; legislação e jurisprudência. 5. ed. São Paulo: Editora Atlas, 2011.

ROSE-AKERMAN, Susan; PALIFKA, Bonnie J. Corruption and Government: Causes, Consequences, and Reform. 2.nd. Cambridge: Cambridge University Press, 2016. 
SANTOS, Carlos Frederico Brito dos. Improbidade Administrativa: reflexões sobre a Lei n. 8.429/92. 2. ed. rev., ampl. e com jurisprudência. Rio de Janeiro: Forense, 2007.

SILVA, De Plácido e. Vocabulário Jurídico. 8. ed. Rio de Janeiro: Forense, 1984.

SILVA, José Afonso da. Curso de Direito Constitucional Positivo. 38. ed. São Paulo: Malheiros Editores, 2014.

VIEIRA, Fernando Grella. A transação na esfera da tutela dos interesses difusos e coletivos: compromisso de ajustamento de conduta. Ação Civil Pública após 30 anos. Coordenação: Edis Milaré. São Paulo: Editora Revista dos Tribunais, 2015.

Mateus Bertoncini é pós-doutor em Direito pela UFSC; doutor e mestre em Direito do Estado pela UFPR; professor titular de Direito Administrativo da Faculdade de Direito de Curitiba; membro do Corpo Docente Permanente do Programa de Mestrado em Direito Empresarial e Cidadania do Centro Universitário Curitiba (UNICURITIBA); professor de Direito Administrativo da Fundação Escola do Ministério Público do Estado do Paraná (FEMPAR) e Procurador de Justiça do Ministério Público do Estado do Paraná.

E-mail: mateusbertoncini@uol.com.br.

Endereço comercial: Rua Chile, n. 1.678, Rebouças, Curitiba - PR. CEP: 80220181. 